\title{
Development of Diagnostic Tests to Identify Deaf Student's Multiple Representations Ability of Physics in SMPLB
}

\author{
Aninditya Dwi Perwitasari ${ }^{1}$, Ani Rusilowati², Sujarwata ${ }^{3}$, Susi Agung Purwaningtyas ${ }^{3}$ \\ 1,2,3,4Physics Education Graduate School, Universitas Negeri Semarang, Indonesia \\ ${ }^{1}$ Corresponding email: anindityadp@gmail.com
}

\begin{abstract}
The purpose of this research is to get the results of deaf students' multi representation capabilities profile analysis in SMPLBN Ungaran. The use of multiple representations is expected to facilitate deaf students to remember and understand the subject matter. The way students understand the material during the learning process varies, especially in children with special needs. Based on the differences in the ability of deaf children to receive and process the subject matter, an assessment is required that may provide information about multirepresentation capabilities. Another goal is to obtain valid and reliable diagnostic test products to measure deaf students' multi-representational skills. The method developed in this study refers to research and development methods. Data on cognitive learning outcomes was obtained through diagnostic tests.
\end{abstract}

Keywords: Diagnostic test, deaf student, multi-representations ability

\section{Introduction}

Children with special needs are children who have abnormalities in physical, mental, or social behaviour (Abdullah, 2013). Children with special needs experience barriers to learning and development and require educational services that match the learning needs of each child (Maftuhatin, 2014). Children with special educational needs $(\mathrm{ABK})$ are children who need psychological education and special assistance as well as special learning conditions during the learning and training process (Didenko \& Frantseva, 2016). ABK needs more attention to improve focus on learning process and maximize the capability to make learning achievement satisfactory (Effendi, Hardiyana, Gustina, 2016). This type of child requires the simplification of learning materials and explanations specifically so that the child is able to understand the material (Haryanto, Marhaeni, Suarni, 2015).

The observation result at SLB Negeri Ungaran shows that there are differences of situation with normal school, one of them in class division. Classes in SLB Negeri Ungaran have been distinguished in several categories, namely: blind, deaf, mentally retarded (mild and moderate), physical disability (mild and moderate), and autism. In accordance with the learning process, hearing impaired is a person who lacks or loses the ability to hear either partly or wholly caused by the non-functioning part or all of the hearing instrument, so that he cannot use his hearing instruments in everyday life, which impact on his life in a complex, on language skills as a very important communication tool Winarsih (2007). Children in the deaf class are classified into four categories: mild hearing loss, moderate hearing loss, severe hearing loss and profound hearing loss (Ashman \& Elkins, 2015). Information obtained when observations at SLB Negeri Ungaran show that all categories of deaf children are joined in the same class.

The use of multiple representations is expected to make it easier for deaf students to remember and understand the subject matter to be longer. Good multiple representation skills will make it easier for students to solve the Physical problems encountered Yusuf \& Setiawan, 2009). Based on differences in the ability of deaf children to receive and process the subject matter, an assessment is needed that can provide information on multiple representation level capabilities. Assessment of learning outcomes including an understanding of the concepts and abilities of multiple representations of students in education can be measured by a test. The test is one of the comprehensive, systematic, and objective evaluation procedures that the results can serve as the basis for decision-making in the teaching process undertaken by teachers (Djaali \& Muljono, 2008).

Tests that can diagnose learning problems experienced by students, such as problems related to multiple representation skills, are diagnostic tests. Diagnostic tests have two main functions, namely identifying problems or difficulties experienced by students, and plan 
follow-up in the form of solutions efforts in accordance with the problems or difficulties that have been identified (Rusilowati, 2017). Based on the problems that have been submitted, the research aimed to develop diagnostic test to identify multiple representation ability level in deaf students.

\section{Methods}

Research on the development of diagnostic tests to identify the ability of multiple representations of deaf students was conducted at SMPLBN Ungaran in July 2018. The subjects of this study were deaf students grade VII. The type of research used is Research and Development or Research and Development ( $R$ \& D), with a focus on developing diagnostic tests to identify the ability of multiple representations of deaf students.

The research and development steps are adapted from Sugiyono (2013). The design validation process involves two experts, namely test and media instrument experts, each consisting of two expert lecturers and teachers. The validation results determine the feasibility of a diagnostic test to identify the multiple representations of deaf students used in the study.

Initial pilot tests were performed to obtain diagnostic item characteristics to identify the multiple representation skills of deaf students. Students' results in the initial trial were made into improvement before entering the next stage of testing. And so on until entering the implementation phase, so that the diagnostic test is produced to identify the ability of multiple representation of deaf student that is feasible to be used and the result of profile analysis of multiple representations ability of Deaf student of SMPLB Ungaran.

\section{Results and Discussion}

\subsection{Empirical and Hypothetical Description}

Some researchers sometimes categorize the score data of their measurements by dividing the score categories into low, high low. The objectives are various, among others, to present the distribution of general research subject scores, see the tendency of subject scores or compare scores between subjects. There are categorizations that use materials in the form of statistics derived from empirical data and statistics from our measuring instruments (hypothetical) (Widhiarso, 2010). Empiric data obtained in this study is shown in Table 1.
Table 1 Empirical Data

\begin{tabular}{cccc}
\hline $\begin{array}{c}\text { Max } \\
\text { Score }\end{array}$ & $\begin{array}{c}\text { Min } \\
\text { Score }\end{array}$ & Mean & $\begin{array}{c}\text { Standard } \\
\text { Deviation }\end{array}$ \\
\hline 49 & 13 & 35 & 9.89 \\
\hline
\end{tabular}

While, table 2 shows the hypothetical data derived from the measuring instrument.

Table 2. Hypothetical Data

\begin{tabular}{cccc}
\hline $\begin{array}{c}\text { Max } \\
\text { Score }\end{array}$ & $\begin{array}{c}\text { Min } \\
\text { Score }\end{array}$ & Mean & $\begin{array}{c}\text { Standard } \\
\text { Deviation }\end{array}$ \\
\hline 60 & 0 & 30 & 10 \\
\hline
\end{tabular}

\subsection{Test Reliability and Diagnostic Test Item Characteristics}

The reliability of the tests in the early stages of testing is very high, at 0.95 . This suggests that diagnostic tests have a high degree of accuracy and consistency of test scores. The average difficulty level of the item is in the medium category. Only 6 out of 30 easy-to-use questions and one question are in very easy category. Differentiating power ranges from 0.20 to 0.40 which means that the problem still needs to be fixed.

\subsection{Multiple Representations Capabilities Profile}

Based on empiric and hypothetical data descriptions, the categorization is shown in Table 3 and Table 4.

Table 3. Category of Empirical Data

\begin{tabular}{cc}
\hline Total Score & Category \\
\hline $0-25$ & Low \\
$26-44$ & Medium \\
$45-60$ & High \\
\hline
\end{tabular}

While, table 4 shows categories based on hypothetical data.

Table 4. Category of Hypothetic Data

\begin{tabular}{cc}
\hline Total Score & Category \\
\hline $0-20$ & Low \\
$21-40$ & Medium \\
$41-60$ & High \\
\hline
\end{tabular}

Preliminary trial results showed that 2 of 9 children had multirepresentation capabilities falling into the high category. Total score obtained reached 47 and 49 from a maximum score of 60. Most other children included in the 
category of being. There is only one child who has multirepresentation skills that are in the low category.

Multiple representations problem in this study is divided into 3 representations, namely: (1) visual representation; (2) verbal representation; (3) mathematical representation. Based on the results of the answer analysis, many students responded appropriately to questions related to visual representation. This shows that deaf students have better visual representation skills than their verbal and mathematical abilities.

\section{Conclusion}

In the early stages, diagnostic tests to identify the level of ability of multirepresentation of deaf students are reliable. The difficulty level of the item is in the medium and easy category. The multirepresentation of students' abilities is largely in the medium category, with a better visual representation ability than the ability of verbal and mathematical representation.

\section{References}

Abdullah, N. (2013). Know the Children with Special Needs. Magistra.

Maftuhatin. (2014). Evaluation of Special Needs Children Learning (ABK) in the Inclusive Class at SD Plus Darul Ulum Jombang. Journal of Islamic Studies.

Didenko, I. A., \& Frantseva, E. N. (2016). Features of Interaction Between Preschool Teachers and "Special" and Their Parents. Procedia, 459-462.

Effendi, D., Hardiyana, B., \& Gustina, I. (2016). Design of Application Program of Science Learning Multimedia Resource Based Materials for Students of SDLB Part B Deaf using Object Oriented Approach. Journal of
SIMETRIS, 605-618.

Haryanto, I., Marhaeni , A., \& Suarni, N. (2015). Effect of Cooperative Learning Model Type STAD Assisted Animation Video on Learning Results Science and Student Creativity SMPLB C Country Denpasar. Effect of Cooperative Learning Model Type STAD Assisted Animation Video on Science Learning Outcomes and Creativity E-Journal Postgraduate Program Ganesha University of Education, 1-8.

Winarsih, M. (2007). Early Intervention for Deaf Children in Language Acquisition. Jakarta: Ministry of Education and Culture. Directorate General of Higher Education.

Ashman, A., \& Elkins, J. (2015). Education For Inclusion and Diversity 5th Edition. Melbourne: Pearson Australia.

Yusuf, M., \& Setiawan, W. (2009). Competency Study of Multirepresentation of Students on Electrostatic Topics. Journal of Education in Information and Communication Technology, 110.

Djaali \& Muljono. (2008). Measurements In The Field Of Education. Jakarta: PT. Grasindo.

Rusilowati, A. (2017). Development of Assessment Instruments. Semarang: Unnes Press.

Sugiyono. (2013). Educational Research Methods Qualitative Approach, Quantitative, and RnD. Bandung: Alfabeta.

Widhiarso, W. (2010). Creating the Measurement Score Result Category from Scale. Faculty of Psychology. Gadjah Mada University. Yogyakarta. 